\title{
Physicochemical Properties, Lipid and Fatty Acid Profile of "Batuan" [Garcinia binucao (Blco.) Choisy] Seed Oil
}

\author{
Elizabeth S. Quevedo ${ }^{1}$, Laura J. Pham², Florinia E. Merca ${ }^{3}$ and \\ Antonio C. Laurena ${ }^{4}$
}

${ }^{1}$ Department of Pure and Applied Chemistry, Visayas State University, Baybay City, Leyte 6521-A, ${ }^{2}$ National Institute of Molecular Biology and Biotechnology, University of the Philippines Los Baños Laguna, ${ }^{3}$ Institute of Chemistry, University of the Philippines, Los Baños, Laguna, ${ }^{4}$ Institue of Plant Breeding, Crop Science Cluster, University of the Philippines Los Baños College, Laguna

\section{ABSTRACT}

The seed oil of "batuan" [Garcinia binucao (Blco.) Choisy] fruit, an indigenous, lesser known, and with promising economic potential, was characterized to evaluate its quality and potential for product development. Using standard AOAC methods, thin layer chromatography and gas chromatography, the physicochemical properties, lipid and fatty acid profile were determined.

Oil yield from "batuan" seeds was high. The extracted oil was yellowish white, soft solid at room temperature. Iodine value, acid value, and peroxide value of the seed oil were low while saponification value was high. Lipid presents in "batuan" seed oil is mostly triglycerides while diglycerides are in low amount. Unsaponifiable matter $(<1.0 \%)$ was abundant in sterol, squalene and beta-carotene, and minor amount of Vit. A palmitate, and -tocopherols. Stearic (C18:0), oleic (C18:1), and palmitic (C16:0) acids were the major fatty acids while arachidic, linoleic, and linolenic acids constitute the minor components. "Batuan" seed oil contained more saturated fatty acids than the unsaturated fatty acids which could be responsible for its being a soft solid at room temperature.

Results of this study show that "batuan" seed oil is of good quality and could be a potential source of valuable oil for food and for other industrial applications.

Key words: Garcinia binucao (Blco.) Choisy, oil, seeds, stearic acid, squalene

\section{INTRODUCTION}

In view of the increasingly scarce natural resources, rise in human population, restrictions and high importation cost of food, which lead to high prices of traditionally important oils for industry, the use of edible endogenous plant species as an alternative way to prevent hunger and malnutrition has become the focus of interest among researchers and scientists. "Batuan" [Garcinia binucao (Blco.) Choisy] (Gutifferae family), a deciduous, edible, lesser known indigenous tree species, is a potential alternative. In the Philippines, "batuan" trees are generally grown in the wild and some are cultivated as garden trees for their sour fruits which have been favorite food acidulants for some people in the Visayas region particularly in Negros Occidental, Iloilo, Samar, Leyte, among other places (Florido and Cortiguerra, 2003). The tree bears hundreds of fruits on average. When mature, the fruit contains numerous, large edible seeds which make up approximately $30 \%$ of the

Correspondence : E. S. Quevedo Address: Department of Pure and Applied Chemistry, Visayas State Univeristy, Baybay City, Leyte6521-A E-mail: elizabethquevedo48@yahoo.com

DOI: 10.32945/atr3722.2015 
whole fruit (Quevedo et al., 2013).

During peak season, the fruits are made into "salted puree", jam, jellies, candies, and dried prunes for the local market. In addition, some of the processed "batuan" products are also transported to other countries including the US and Europe for Filipinos pining for "batuan's" unique flavor from home (Cojuangco, 2012; Tajanlangit, 2011). In most fruit processing methods, the seeds are thrown away as waste due to the consumers' lack of knowledge on its nutritional value, thus limiting their utilization. Several reports show that the Garcinia, an important genus of the Guttiferae family, is well-known to be rich in components with potential health benefits and numerous uses. Just like the seeds of its close relatives, G. indica, G. kola, G. mangostana, among others which were found to contain high oil, essential fatty acids, vitamins and other components that play an important role in the human health and economic benefits (SCUC, 2008; Adeyusi et al., 2012; Vidhate \& Singhal, 2013), seeds of "batuan" may also have high potential in terms of nutritional values and commercial uses.

Literature search showed that the physicochemical properties, lipid and fatty acid composition of "batuan" seeds oil have not been reported and published to date. In this study, the physicochemical properties were determined while triglycerides, oleic acid, stearic acid, palmitic acid, arachidic and minor amount of omega-3 fatty acids were identified to be present in "batuan" seed oil. Phytosterols, beta-carotene and squalene were also identified to be present in the unsaponifiable fraction.

This article presents the results on the characterization of "batuan" seed oil in terms of physicochemical properties, lipid, and fatty acid profile. An attempt was also made to determine the composition of the unsaponifiable matter in "batuan" seed oil.

\section{MATERIALS AND METHODS}

Material

Seeds of matured "batuan" fruits were obtained from trees grown at the Pomology Project of the Visayas State University (VSU), Visca, Baybay City, Leyte.

Pure standards of 1-stearoyl-rac-glycerol, glyceryl dioleate, glyceryl trioleate, stigmasterol, myristic acid, ergosterol, beta-carotene $(\beta$-car), squalene were purchased from Sigma Chemical Co. Liquid solvents such as diethylether, hexane, ethylacetate, and formic acids were purchased from J.T. Baker Chemical Co. (Phillipsburg, NJ), and/or RCL LabScan. All other solid reagents used were of analytical grade.

\section{Methods}

\section{Sample Preparation}

The seeds of "batuan" were separated manually from the other parts of the fruits using a previously cleaned chopping board and sharp, stainless knife. These were dried at $70^{\circ} \mathrm{C}$ for $16 \mathrm{~h}$ using the fabricated food cabinet dryer of VSU's Department of Food Science and Technology. The endosperms of the dried seed samples (Figure 1) were separated by cutting the seeds into halves; they were then oven-dried at $70^{\circ} \mathrm{C}$ for $5 \mathrm{~h}$, cooled, ground into powder using a homogenizer/blender (Osterizer), passed through a 60-mesh sieve, stored in an air-tight plastic container (Ziploc), and kept at room temperature prior to oil extraction.

\section{Extraction of "Batuan" Seed Oil}

Extraction of oil from "batuan" seed endosperm was done using the soxhlet method (AOAC, 1995). Replicated samples of dry, powdered seed endosperm were extracted 
using hexane (b.p. $50-70^{\circ} \mathrm{C}$ ) in a soxhlet extractor for $8 \mathrm{~h}$. The solvent was evaporated using a rotary evaporator at $50-80^{\circ} \mathrm{C}$, followed by passing nitrogen gas $\left(\mathrm{N}_{2}\right)$ through the oil. The extracted oil (Figure 2) was weighed, stored in a glass bottle, and kept at room temperature. Oil content was estimated and expressed in percent dry seed weight.

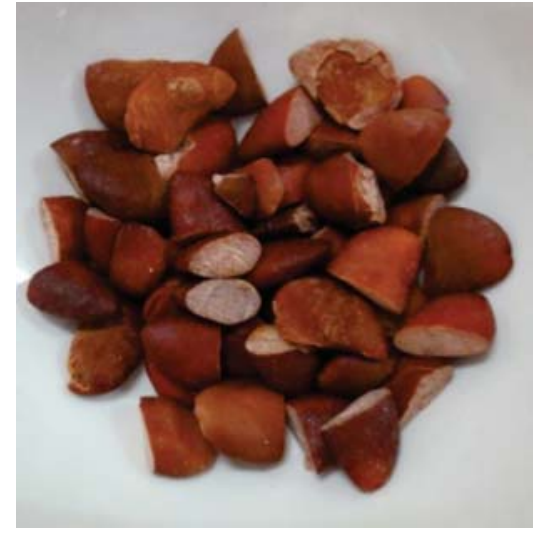

Figure 1. Dried mature seed endosperms of "batuan" [G. binucao (Blco.) Choisy].

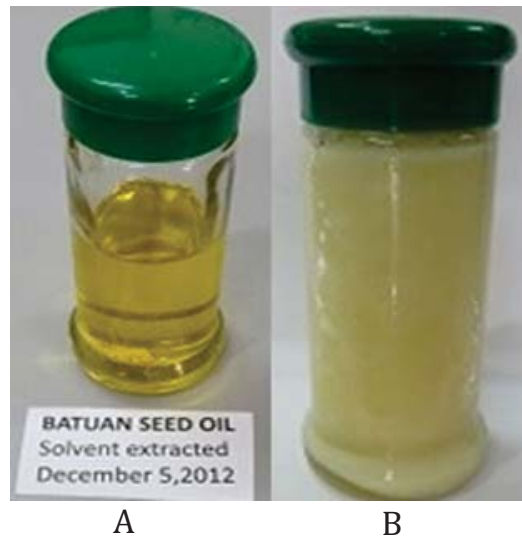

Figure 2. "Batuan", [G. binucao (Blco.) Choisy] seed oil. A) after extraction, B) at room temperature

\section{Determination of the Physical and Chemical Properties of Seed Oil}

The color and state of extracted oil were noted at room temperature by visual inspection. Melting point was determined using the capillary tube method; density and specific gravity of the oil $\left(38^{\circ} \mathrm{C} / 38^{\circ} \mathrm{C}\right.$ ), using a pycnometer (AOAC, 1995); and oil viscosity $\left(35^{\circ} \mathrm{C} / 35^{\circ} \mathrm{C}\right)$, with the Cannon-Fenske viscometer, at the Analytical Service Laboratory of the Institute of Food Science, University of the Philippines, Los Baños (UPLB). Analyses of acid value (AOAC, 1997), peroxide value, iodine value, saponification value (AOAC, 1995), and unsaponifiable matter (AOAC, 1977) content were also carried out at the Analytical Service Laboratory, Institute of Plant Breeding, UPLB. The molecular weight of the fatty acid was estimated based on its fatty acid profile using the following formula (www.uidaho.edu/ devs//Research/ Calculators/ Molecularweights _ calculator.html):

$$
\text { Average molecular weight of fatty acids }=\sum f i / \sum(f i / M W i)
$$

where: $f i=$ weight fraction of a reported fatty acid

Molecular Weight of the Triglyceride (oil molecule) $=3 \mathrm{x}$ average MW of fatty acids +38.049

where: $38.049=$ the weight of glycerol backbone

\section{Determination of the Lipid Profile of Seed Oil}

Pre-activated silica gel G-coated TLC plates $(20 \mathrm{~cm}$ x $20 \mathrm{~cm}$ ) were spotted with 50-100 $\mu \mathrm{g}$ of standards and samples dissolved in hexane, allowed to dry, and developed using hexane:diethyl ether:formic acid (80:20:2 v/v) solution. The spots were visualized using iodine vapor and quantified using the CP Atlas (Cross Platform Advance Thin Layer and Gel Analysis) v.2 software. 


\section{Measurement of fatty acids}

Fatty acid analysis was completed at the SGS Philippines, Inc., Makati City, Philippines. Fatty acids which were transformed to fatty acid methyl esters (FAMEs) following the SGS Philippines, Inc. in-house method (P-LAB-005-INSTRU) based on the AOAC official method 969.33 and 996.06 (AOAC, 2012) were analyzed on Agilent 7890A GC system equipped with Stabilwax DA $(30 \mathrm{~m} \times 0.32 \mathrm{~mm} \times 0.25 \mu \mathrm{m})$ column, and a flame ionization detector. The injection temperature was set at $230{ }^{\circ} \mathrm{C}$. The column temperature was programmed from $80^{\circ} \mathrm{C}(3 \mathrm{~min})$ to $240{ }^{\circ} \mathrm{C}(8 \mathrm{~min})$ at $10^{\circ} \mathrm{C}$ per min. Identification of fatty acids present in the sample was done by comparing the retention time of sample peaks with that of authentic standards. Percent relative fatty acid was calculated on the basis of the ratio of the peak area of a fatty acid species to the total peak area of all fatty acids in the oil sample.

\section{Analysis of Unsaponifiable Matter Components}

Pre-activated silica gel G-coated TLC plates $(20 \mathrm{~cm}$ x $20 \mathrm{~cm})$ were spotted with 50-100 $\mu \mathrm{g}$ of standard and the unsaponifiable fraction of seed oil dissolved in hexane, allowed to dry, and developed using hexane:ethyl acetate $(80: 20 \mathrm{v} / \mathrm{v})$ solution. Spots were sprayed with $0.01 \%$ rhodamine $6 \mathrm{G}$ in ethanol and visualized under UV light $(254 \mathrm{~nm})$ and quantified using the CP Atlas v.2 software.

\section{Statistical Analysis}

Results were expressed as the means \pm SD of three replications, except for fatty acid composition.

\section{RESULTS AND DISCUSSION}

\section{Physical and Chemical Properties of "batuan" Seed Oil}

Oil content is an important factor that determines the intrinsic commercial value of "batuan" fruit. Table 1 shows that the oil yield from "batuan" seed endosperm was high (55.10\% dry basis) compared with the reported values of $41-53.56 \%$ for shea nuts (Okullo et al., 2010) and $42 \%$ for palm kernel nut (Atasie and Akinhanmi, 2009). Furthermore, the extracted oil (Figure 2) has nutty, pleasant smell, slightly yellowish in color and is soft solid at room temperature $\left(30^{\circ} \mathrm{C}\right.$ ), similar to that of tallow (www.bhj.com) and cocoa butter (http://www.getridofacne.co.uk/wp-content/uploads/2014/07/cocoa-butter.jpg). However, its melting point $\left(36.67 \pm 0.58^{\circ} \mathrm{C}\right)$ was lower than the reported $42^{\circ} \mathrm{C}$ for tallow and comparable with the $36^{\circ} \mathrm{C}$ noted in cocoa butter (Liendo et al., 1997; NRA, 2003). Melting point is associated with the degree of unsaturation, which in turn is reflected by the iodine value. The yellow color of the oil after extraction was attributed to the presence of natural pigments. The density ${ }_{38^{\circ} \mathrm{C}}$ of the seed oil $\left(0.8898 \mathrm{~g} \mathrm{~mL}^{-1}\right)$ was also comparable with the reported 0.894-0.899 $\mathrm{g} \mathrm{mL}^{-1}$ for sunflower oil (Salunshke et al., 1992) and the specific gravity $_{38^{\circ} \mathrm{C}}(0.9016 \pm 0.001)$ was similar to coconut oil's $0.88 \pm 0.02$ (Obasi et al., 2012) and to $0.98 \pm 0.01$ of G. mangostana (Ajayi et al., 2007).

Acid value (AV) represents the free fatty acid content due to enzymatic degradation or chemical oxidation and is an indicator of the edibility and suitability of the oil for industrial use. Results showed that "batuan" seed oil had low AV $\left(2.70 \pm 0.00 \mathrm{mg} \mathrm{KOH} \mathrm{g}^{-1}\right.$ oil $)$ and this value is within the expected range $\left(0-3 \mathrm{mg} \mathrm{KOH} \mathrm{g}^{-1}\right)$ for edible cooking oil that was recommended by the Codex Alimentarius Commission (Abayeh et al., 1998). Likewise, the AV of "batuan" seed oil (BSO) also compares favorably with reported values for some commonly used vegetable oils such as $2.06 \pm 0.32 \mathrm{mg} \mathrm{KOH} \mathrm{g}^{-1}$ forcoconut oil (Obasi et al., 
2012); $2.31 \pm 0.08 \mathrm{mg} \mathrm{KOH} \mathrm{g}{ }^{-1}$ for sesame, soybean, and sunflower oils (Ajayi et al., 2007), but lower than the reported $11.60 \mathrm{mg} \mathrm{KOH} \mathrm{g}^{-1}$ for palm kernel oil (Atasie and Akinhanmi, 2009). The low AV of the oil of "batuan" seed suggests that it could be a good edible oil with a long shelf-life and that it would involve an easier refining process (Siddhuraju et al., 2001).

Table 1. Physical and chemical properties ${ }^{1}$ of "batuan" [G. binucao (Blco.) Choisy] seed oil.

\begin{tabular}{lc}
\hline Physicochemical & Values \\
Properties & $55.10 \%$ (dry basis) \\
\hline Oil Content & pleasant nutty smell \\
Odor & Clear, yellow liquid $\left(30^{\circ} \mathrm{C}\right)$ \\
Color & Soft solid \\
State at room temperature & $36.67 \pm 0.58^{\circ} \mathrm{C}$ \\
Melting point & $0.9016 \pm 0.001$ \\
Specific gravity $\left(38^{\circ} \mathrm{C}\right)$ & $0.8898 \mathrm{gL}^{-1}$ \\
Density $\left(30^{\circ} \mathrm{C}\right)$ & $39.98 \pm 0.87$ \\
Viscosity $(\mathrm{cps})$ & $2.70 \pm 0.00$ \\
Acid value $(\mathrm{mg} \mathrm{KOH} \mathrm{g-1})$ & $1.13 \pm 0.00$ \\
Peroxide value $\left(\mathrm{meq} \mathrm{kg}^{-1}\right)$ & $0.133 \pm 0.00 \%$ \\
Unsaponifiable matter $(\%)$ & $45.99 \pm 0.82$ \\
Iodine value (mg $\left.100 \mathrm{~g}^{-1}\right)$ & $267.63 \pm 11.19$ \\
Saponification Number $\left(\mathrm{mg} \mathrm{KOH} \mathrm{g}^{-1}\right)$ & 887 \\
Estimated Molecular Weight $\left(\mathrm{g} \mathrm{mol}^{-1}\right)$ & \\
\hline
\end{tabular}

${ }^{1}$ Values are mean \pm SD in triplicate analysis (dry basis)

Peroxide value (PV) is one of the most widely used parameters for the level of oxidation in oils and fats. It is a measure of the concentration of peroxides and hydroperoxides formed in the initial stages of lipid oxidation. In general, the lower the PV value, the fresher the oil is. Furthermore, the higher the degree of saturation, the more stable the oil, and the slower that peroxides are likely to form. This is due to the absence of double bonds in the saturated fatty acid chains that makes the oil not susceptible to oxidative processes. Thus, undesirable products (aldehydes, ketones, etc.) with offensive odor and toxic properties that lower the nutritional value of the saturated fatty acid-rich oil are less likely to be formed.

For BSO, the peroxide value obtained was $1.13 \pm 0.00 \mathrm{meq} \mathrm{kg}^{-1}$ and is comparable with the $1.7 \mathrm{meq} \mathrm{kg}^{-1}$ for palm kernel oil (Atasie and Akinhanmi, 2009) and the $1.52 \pm 0.05 \mathrm{meq}$ $\mathrm{kg}^{-1}$ for soybean oil (Nehdi, 2011). Ojeh (1981) reported that oils with high PVs are unstable and easily become rancid. Fresh oils usually have PVs below $10 \mathrm{mg} \mathrm{g}^{-1}$ oil, whereas the PVs of rancid oils range from 20.0 to $40.0 \mathrm{mg} \mathrm{g}^{-1}$ oil (Pearson, 1976). Furthermore, the Codex Alimentarius Commission (1982) stipulates a maximum peroxide level of not more than 10 mg peroxide oxygen $\mathrm{kg}^{-1}$ oil. For "batuan" seed oil, the obtained PV was less than 10, implying a good property with low levels of rancidity and better shelf-life.

The iodine number or value (IV) gives information on the degree of unsaturation of the fatty acids in oil. It is defined as the weight of iodine absorbed by $100 \mathrm{~g}$ of an oil or fat. The higher the iodine number, the more unsaturated the oil or fat becomes. As a general rule, a sample is considered a fat if the iodine number is 0-70; and an oil, if the value exceeds 70 (http:/ / amrita.vlab.co.in/?sub=3\&brch=63\&sim=1111\&cnt=2).

The "batuan" seed oil has an iodine value of $45.99 \pm 0.8 \mathrm{mg} 100 \mathrm{~g}^{-1}$ which is

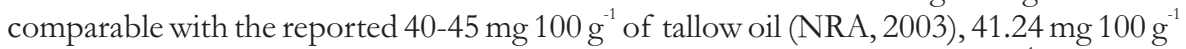
for palm kernel oil (Atasie and Akinhanmi, 2009), and 39.21-41.37 mg $100 \mathrm{~g}^{-1}$ of shea oil (Okullo et al., 2010). "Batuan" seed oil low IV suggests low unsaturation level which contributes to a soft "batuan" fat or butter, making it less susceptible to oxidative rancidity 
and deterioration during storage. Moreover, this implies that it could be used as a raw material for vegetable oil-based ice cream (Oderinde et al., 2009). The low IV value of $\mathrm{BSO}$ is also consistent with its fatty acid composition obtained using gas chromatography.

Results of the analysis on the unsaponifiable matter (UM) content of the seed oil was also lower $(0.133 \pm 0.00022 \%)$ than those of some edible oils, suggesting low levels of antioxidants and other lipid-associated substances such as sterols, fat-soluble vitamins, hydrocarbons, and pigments (Bastic et al., 1978; Salunske et al., 1992).

Saponification number or value (SV) represents the number of milligrams of potassium hydroxide required to saponify $1 \mathrm{~g}$ of fat under specified conditions. Results showed that the saponification value (SV) of "batuan" seed oil was high $(267.63 \pm 11.19$ $\mathrm{mg} \mathrm{KOH} \mathrm{g} \mathrm{g}^{-1}$ ), which means that more alkali would be required to neutralize the available free fatty acids liberated from the oil. The high saponification value obtained is related to the estimated average molecular weight of the fatty acids $\left(887 \mathrm{~g} \mathrm{~mol}^{-1}\right)$ present in the oils. It is an important property that influences the organoleptic properties of fat such as hardness, flavor and aroma (Liendo et al., 1997). Since the SV of "batuan" seed oil is comparable with the $252.44 \pm 1.39 \mathrm{mg} \mathrm{KOH} \mathrm{g}^{-1}$ reported for coconut oil (NRA, 2008; Obasi et al., 2012) and $232.81 \mathrm{mg} \mathrm{KOH} \mathrm{g}^{-1}$ for palm kernel oil (Atasie and Akinhanmi, 2009), "batuan" oil has great potential in soap-making, cosmetics, as a cocoa-butter substitute, as well as in high-temperature cooking oil manufacturing industries.

\section{Liquid Profile Analysis}

The glycerides and the components of the UM of "batuan" seed oil were separated by thin layer chromatography based on differences in polarity and therefore degree of chromatographic adsorption. Identification was done by comparing $\mathrm{Rf}$ values with those of pure compounds and those in the literature. The more polar components are strongly adsorbed, resulting in slower upward movement on the TLC plate. The glycerides were eluted on the TLC plates with mixtures of solvents of adjusted polarities as follows: monoglycerides, diglycerides, and triglycerides. The chromatogram showed three spots for "batuan" seed oil (Figure 3): the first two very closely spaced spots had been identified as diglycerides through their Rf values $(0.258$ and 0.308$)$, which are similar to the Shahnaz et al. (2004) reported $\mathrm{Rf}$ values of 0.29 for 1,2 diglycerides and 0.33 for 1,3 diglycerides (Table 2). Spots 1 and 2 were suspected to be for diglycerides and spot 3 as being due to triglycerides with the obtained $\mathrm{Rf}$ value $(0.867 \pm 0.006)$ very closed to $\mathrm{Rf}$ value $(0.87)$ of the triolein standard. Triglycerides $(95.47 \pm 1.99 \%)$ constitute the major components of the lipids in "batuan" seed oil, whereas the diglycerides $(4.53 \pm 1.99 \%)$ were present in trace amounts (Table 2 and Figure 3).

The high triglyceride content obtained further implies that the oil extraction process used was good and did not result in degradation of the triglyceride structure.

\section{Unsaponifiable Matter (UM) Analysis}

The components of the UM of "batuan" seed oil were separated by thin layer chromatography based on differences in polarity and therefore degree of chromatographic adsorption. Identification was done by comparing $\mathrm{Rf}$ values with those of pure compounds and in the literature.

Figure 4 shows that the minor components of the UM of the seed oil with the most number of double bonds moved faster upward on the plate than those which are saturated. The observed order of elution was as follows: sterol, $\beta$-tocopherol, $\alpha$-tocopherol, vitamin A palmitate, beta-carotene, and squalene. Thus, component 1 was identified as sterol; component 2, $\beta$-tocopherol; component 3 - $\alpha$-tocopherol; component 4 , vitamin A palmitate; and component 5 , squalene being in close association with beta-carotene, respectively (Figure 4). 
The overlap in spot 5 is probably due to the structural similarity between squalene and beta-carotene, which are both nonpolar compounds. Complete separation of the two may require the application of a more suitable temperature and the use of another solvent system (Kelly, 1999).
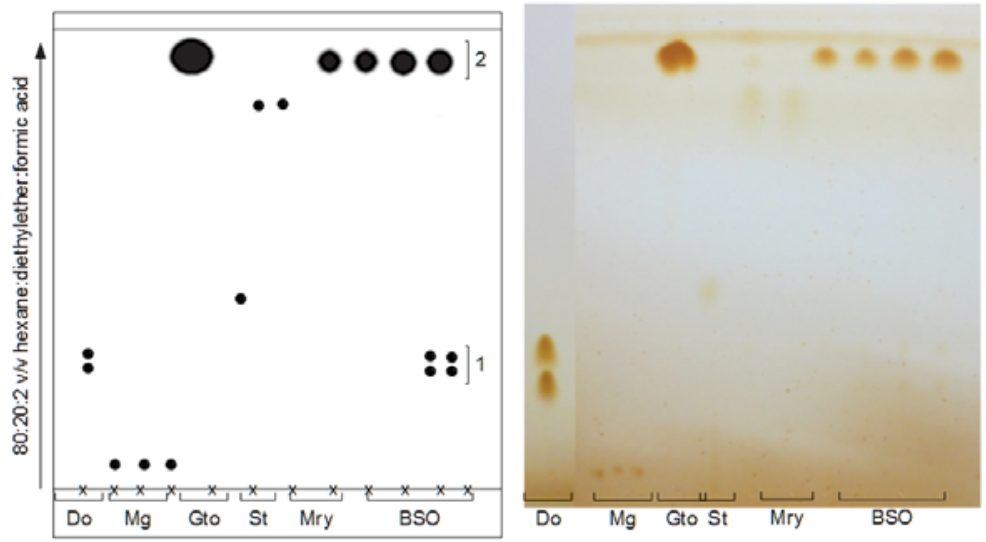

Lane:

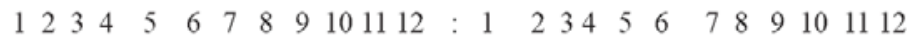

Figure 3. Thin layer chromatogram of lipid standards and "batuan" [G. binucao (Blco.) Choisy] seed oil (BSO). Standards: Lane 1 - dioleate standard (Do), Lanes 2 to 4 - monoglycerol (1stearoyl-rac-glycerol) standard (Mo), Lane 5 - glyceryl trioleate standard (Gto), Lane 6 stigmasterol standard (St), Lanes $7 \& 8$ - myristic acid (Mry); Sample (BSO): Lanes 9 to 12. Developing solvent: hexane:diethylether:formic acid (80:20:2 v/v); detecting agent: iodine crystal vapor.

Table 2. Rf values, identities and estimated values (\% dry weight basis) of glycerides present in "batuan" [G. binucao (Blco.) Choisy] seed oil.

\begin{tabular}{lccc}
\hline \multicolumn{1}{c}{ COMPONENT } & RF & IDENTITY & $\begin{array}{c}\text { ESTIMATED } \\
\text { VALUE }(\%)^{\mathrm{b}}\end{array}$ \\
\hline 1-stearoyl-rac-glycerol & 0.082 & & \\
1,2 diglyceride & $0.29^{\mathrm{a}}$ & & \\
1,3 diglyceride & $0.33^{\mathrm{a}}$ & & \\
glyceryl trioleate & 0.87 & & \\
myristic acids & 0.782 & & \\
stigmasterols & 0.417 & & $1.89 \pm 1.40$ \\
batuan seed oil & & & $2.64 \pm 1.91$ \\
1 & $0.258 \pm 0.03^{\mathrm{b}}$ \\
2 & $0.308 \pm 0.01^{\mathrm{b}}$ & diglycerides \\
3 & $0.867 \pm 0.01^{\mathrm{b}}$ & diglycerides & triglycerides \\
\hline
\end{tabular}

${ }^{a}$ Shahnaz et al. (2004), ' Data were averages of four replications.

Table 3 further shows that although the unsaponifiable fraction of "batuan" seed oil was less than $1.0 \%$ (Table 1$)$, it is still rich in phytosterols $(49.80 \pm 0.03 \%)$ and squalene together with beta-carotene $(37.90 \pm 13.04 \%)$. In addition, $\beta$-tocopherol $(3.56 \pm 1.85 \%), \alpha$ tocopherol $(2.54 \pm 1.56 \%)$, and vitamin A palmitate $(6.21 \pm 2.29 \%)$ were present in minor amount. The results suggest that "batuan" oil is a good source of plant sterols, squalene, and beta-carotene, which reportedly have beneficial effects on health (Rao et al., 1998; Kelly, 1999; Visioli et al., 2000; Borthwick, 2011). 

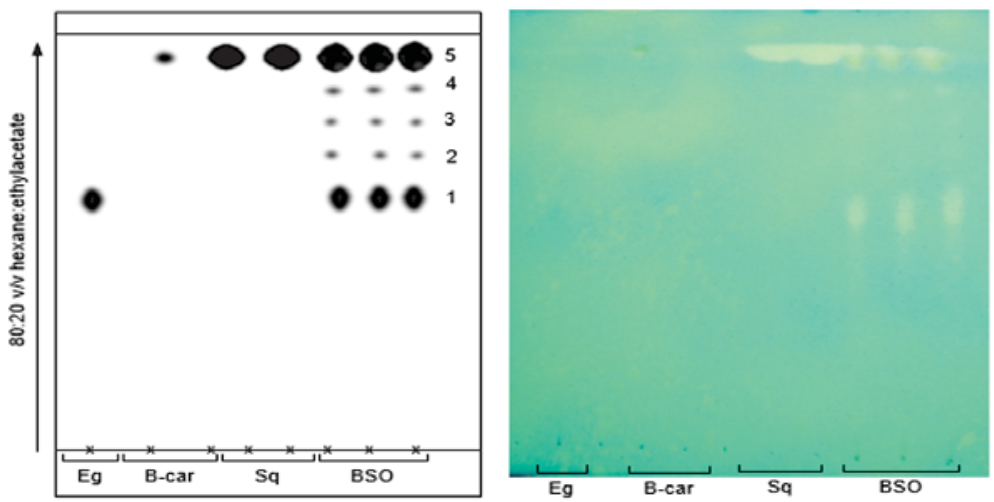

\section{Lane: $1 \begin{array}{lllllllllllllll}1 & 2 & 3 & 4 & 5 & 6 & 7 & : & 1 & 2 & 3 & 4 & 5 & 6 & 7\end{array}$}

Figure 4. Thin layer chromatogram of the standards and unsaponifiable matter of "batuan" [G. binucao (Blco.) Choisy] seed oil (BSO). Standards: Lane 1- ergosterol standard (Eg), Lane 2 -beta-carotene standard ( $\beta$-car), Lanes $3 \& 4$ - squalene standard $(\mathrm{Sq})$; Sample (BSO) - Lanes 5 to 7.

Developing solvent: hexane: ethyl acetate $(80: 20 \mathrm{v} / \mathrm{v})$; Detecting agent: UV $(254 \mathrm{~nm})$.

The beneficial effects of plant sterols, squalene, and beta-carotene include protection against a) cardiovascular diseases by interfering with cholesterol absorption in the small intestine, thereby lowering the blood plasma cholesterol level (Borthwick, 2011); b) cancer by altering the transfer of nutrients from cell to cell (Rao et al., 1998; Kelly, 1999); and c) stress and inflammation by inhibiting excessive production of cortisol (Louw et al., 2002). The occurrence of these important micronutrients in the unsaponifiable fraction suggests that "batuan" seed oil has good potential as a valuable alternative source of nutrients.

Table 3. Rf values, identities and estimated values (\% dry weight) of the components of the unsaponifiable fraction of "batuan"[G. binucao (Blco.) Choisy] seed oil.

\begin{tabular}{|c|c|c|c|}
\hline COMPONENT & RF VALUE & IDENTITY & $\begin{array}{l}\text { ESTIMATED } \\
\text { VALUE }(\%)^{\mathrm{a}}\end{array}$ \\
\hline Sterol & 0.578 & & \\
\hline Beta-carotene & 0.946 & & \\
\hline Squalene & 0.951 & & \\
\hline$\alpha+\gamma$-tocopherol & $0.65^{\mathrm{b}}$ & & \\
\hline$\alpha$-tocopherol & $0.70^{\mathrm{b}}$ & & \\
\hline$\beta$-tocopherol & $0.69^{c}$ & & \\
\hline$\alpha$-tocotrienol & $0.58^{c}$ & & \\
\hline$\delta$-tocopherol & $0.55^{\mathrm{b}}$ & & \\
\hline Vitamin A palmitate & $0.82^{c}$ & & \\
\hline \multicolumn{4}{|l|}{ Batuan Seed Oil } \\
\hline 1 & $0.54 \pm 0.03$ & sterol & $49.80 \pm 14.44$ \\
\hline 2 & $0.69 \pm 0.02$ & $\beta$-tocopherol & $3.56 \pm 1.85$ \\
\hline 3 & $0.74 \pm 0.03$ & $\alpha$-tocopherol & $2.54 \pm 1.56$ \\
\hline 4 & $0.85 \pm 0.01$ & Vitamin A palmitate & $6.21 \pm 2.29$ \\
\hline 5 & $0.95 \pm 0.00$ & squalene $/ \beta$-carotene & $37.90 \pm 13.04$ \\
\hline
\end{tabular}

${ }^{a}$ Data were averages of three measurements. ${ }^{b}$ Karleskind (1996) ${ }^{c}$ Lichtenthaler et al. (1982) 


\section{Fatty Acid Composition}

The most useful chemical feature of an oil is its fatty acid composition. Pritchard (1991) stated that many of the chemical tests for oil identity or purity can be related to fatty acid content. Table 4 and Figure 5 revealed that BSO has higher proportion of saturated fatty acids (52.26\%) than the unsaturated fatty acids (47.74\%), which could account for its soft solid state at room temperature.

Table 4. Fatty acid composition (dry weight basis) of "batuan" [G. binucao Blco.) Choisy] seed oil.

\begin{tabular}{llc}
\hline Fatty Acid & Fatty Acid & Percent Composition $^{a}$ \\
\hline C16 & Palmitic acid & 1.48 \\
C18 & Stearic acid & 50.47 \\
C18:1 & Oleic acid & 47.35 \\
C18:2 & Linoleic acid & 0.34 \\
C18:3 & Linolenic acid & 0.04 \\
C20 & Arachidic acid & 0.29 \\
Saturated & & 52.26 \\
Unsaturated & & 47.75 \\
Unidentified & & 0.03 \\
\hline
\end{tabular}

${ }^{\mathrm{a}}$ Data are averages of two measurements.

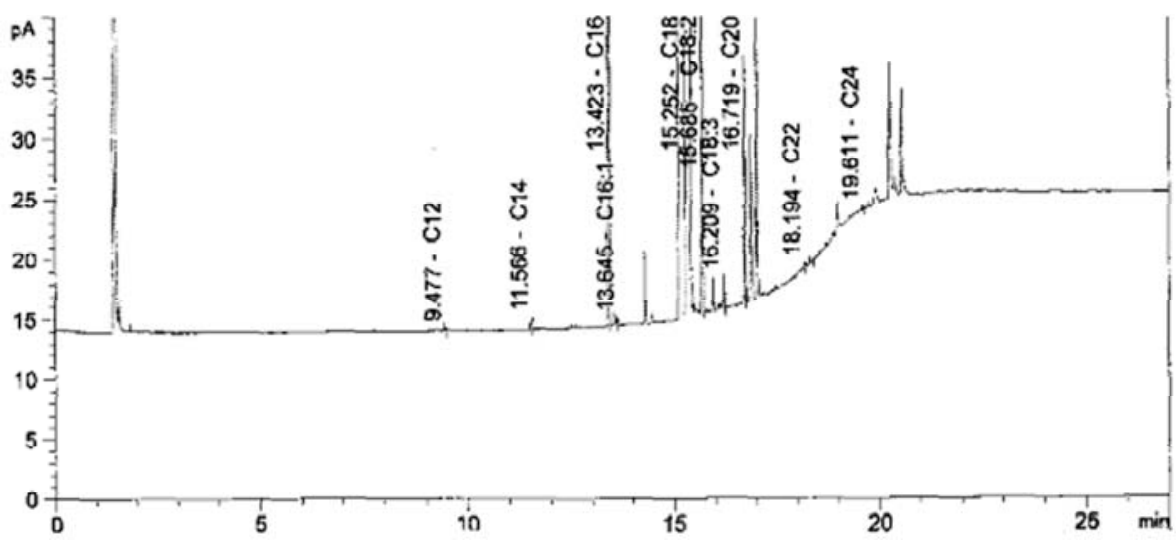

Figure 5. Gas chromatogram of the fatty acid content of "batuan" [G. binucao

(Blco.) Choisy] oil. (C16 - Palmitic acid; C18 - Stearic acid;

C18:1 - Oleic acid; C18:2 - Linoleic acid; C18:3 - Linolenic acid;

C20 - Arachidic acid).

The latter observation is similar with those observed for cocoa butter but BSO and cocoa butter differ on the amount of fatty acids contained. For "batuan" seed oil, oleic acid $(47.35 \%)$, linoleic acid (0.34\%) and linolenic acid (0.04\%) accounted for the unsaturated portion, whereas stearic acid (50.47\%), palmitic acid (1.48\%) and arachidic acid ( $0.29 \%)$ for the saturated fatty acid profile. The percentage of unknown fatty acids in the seed oil was found to be $0.03 \%$. In cocoa butter, Chakrabarty (2003) reported that the unsaturated fatty acids are monounsaturated oleic acid (34-36.9\%) and polyunsaturated linoleic acid (2.7$4 \%$ ), while the saturated fatty acids are palmitic acid (23-27\%) and stearic acid (32.6$35.436 \%$ ). Compared with the oleic acid content $(71.21 \%)$ of Moringa oil in the Philippines (Yap, 2011), that of "batuan" seed oil was lower. Moreover, the oleic acid content in "batuan" seed oil was also relatively lower (47.35\%) than the 55-83\% reported 
for olive oil (Kiritsakis and Markakis, 1987) but higher than the reported 25\% for soybean oil (Rao et al., 1998). On the other hand, $50.47 \%$ stearic acid content of "batuan" seed oil is quite higher compared to the $0.5-5.0 \%$ reported for olive oil (Kiritsakis and Markakis, 1987); 5.88\% for Moringa oil (Yap, 2011); and 39.2\% in palm oil (Downey, 2006). Thus, "batuan oil" could be a good source of stearin for food manufacturing applications. Moreover, the higher ratio of saturated to unsaturated fatty acids in "batuan" seed oil explains its semi-solid state at normal room temperature and further confers greater stability and resistance to oxidation compared with other vegetable oils.

\section{CONCLUSION}

Based on the results of the study, it can be concluded that the "batuan" seed oil has good physicochemical properties and could be an important sources of trans fat-free natural ingredient for food and industrial applications.

\section{ACKNOWLEDGEMENT}

The authors would like to thank the DA-BIOTEC Program and the Visayas State University for the financial support; the Fats and Oils laboratory, BIOTECH-UPLB for the technical support; faculty/staff of DFST, DoPAC-VSU; Analytical Service Laboratories of IFS, IPB BIOTECH-UPLB; and SGS, Philippines Inc; the Quevedo Family, relatives and friends for their extraordinary and generous help in this study.

\section{REFERENCES}

ADEYUSI, A.O., I.K. LUMM, F.B. ADARAMOLA, and O.W. BITOYE. 2012. Nutritional and phytochemical screening of Garcinia kola. Advance J. of Food Sci. and Technol. 4(1):9-14.

AJAYI, I.A., R.A. ODERINDE, B.O. OGUNKOYA, A. EGUNYOMI, and V.O. TAIWO. 2007. Chemical analysis and preliminary toxicological evaluation of Garcinia mangostana seeds and seed oil. Food Chem. 101:999-1004.

ABAYEH, O.J., E.A. AINA, and C.O. OKUONGHAE. 1998. Science forum. J. Pure Appl. Sci. 1(1): 17-23.

[AOAC] Association of Official Agricultural Chemists. 2012. Official methods of analysis. $19^{\text {th }}$ ed. Washington, D.C.: AOAC.

[AOAC] Association of Official Agricultural Chemists. 1997. Official methods of analysis. $16^{\text {th }} \mathrm{ed}$. Washington, D.C.: AOAC.

[AOAC] Association of Official Agricultural Chemists. 1995. Official methods of analysis. $16^{\text {th }}$ ed. Washington, D.C.: AOAC.

ATASIE, V.N. and T.F. AKINHANM. 2009. Extraction, compositional studies and physico-chemical characteristics of palm kernel oil. Pak. J. Nutr. 8(6): 800-803.

BASTIC, M., L. BASTIC, J.A. JABANOIC, and G. SPITELLER. 1978. Hydrocarbons and other weakly unsaponifiables in vegetable oils. J. Am. Oil Chem. Soc. 55: 886-892.

BORTHWICK, L. 2011. Plant sterols: do they work? Retrieved August 21, 2013 from http://www.besthealthmagca/eat-well/ nutrition/plant-sterol-do-they-work.

CHAKRABARTY, M.M. 2003. Chemistry and Technology of Oils and Fats. New Delhi: Allied Publisher PVT, LTD. p524.

CODEX ALIMENTARIUS COMMISSION. 1982. ( $1^{\text {st }}$ ed.). Recommended internal standards for edible fats and oils. Vol. XI. Rome: FAO/WHO.

COJUANGCO, G.O. 2012. Binukao-A source of my gastronomical treats. In: Inquirer Opinion. Accessed on July 26, 2013 from: http://opinion.inquirer.net/41012/ binukau\#ixzz2YcY4mqGr. 
DOWNEY, K. 2006. Oilseeds-major. In: BLACK, M., BEWLEY, J.D. and P. HALMER. editors. The Encyclopedia of Seeds: science, technology, and use. United Kingdom: CAB International. p. 455-456.

FLORIDO, H.B. and F.F. CORTIGUERRA. 2003. Lesser known edible tree species. Res. Inf. Ser. Ecosys. 15(3):7-8.

KARLESKIND, A. 1996. Oils and Fats Manual: A Comprehensive Treatise Vol. I. Paris, France:Lavoisier Publishing. 806pp.

KELLY, G.S. 1999. Squalene and its potential clinical use. Altern. Med. Rev. 4(1): 29-36.

KIRITSAKIS, A. and P. MARKAKIS. 1987. Olive oil: a review. Adv Food Res 31: 453-479.

LICHTENTHALER, H.K., K. BORNER and C. LILJENBERG. 1982. Separation of prenylquinones, prenylvitamins and prenols on thin-layer plates impregnated with silver nitrate. J. Chrom. pp196-201, 242.

LIENDO, R., F.C. PADILLA, and A. QUINTANA. 1997. Characterization of cocoa butter extracted from Criollo cultivars of Theobroma cacao L. Food Res. Int'l. 30(9):727-731.

LOUW, I., A. HALLAND, P.J.D. BOUIC, M. FREESTONE, and J. LAMPRECHT. 2002. A pilot study of the clinical effects of a mixture of beta-sitosterol and betasitosterol oxidase in active rheumatoid arthritis (ra). Am.J. Clin. Nutr. 75(2):351S.

NEHDI I. 2011. Characteristics, chemical composition and utilization of Albizia julibrissin see oil. J. Ind. Crops Prod. 33: 30-34.

[NRA] National Renderers Association, Inc. 2008. Pocket information manual: a buyer's guide to rendered products. Virginia: NRA. p. 20,26, 24.

OBASI, N.A., J. UKADILONU, E. EZE, E.I. AKUBUGWO, and U.C. OKORIE. 2012. Proximate composition, extraction, characterization and comparative assessment of coconut (Cocos nucifera) and melon (Colocynthis citrullus) seeds and seed oils. Pak.J. Biol. Sci. 15(1):1-9.

ODERINDE, R.A., E.A. AJAYI, and A. ADEWUYI. 2009. Characterization of oil seed and seeds oil of Hura crepitans and the kinetics of degradation of the oil during heating. Electron J. Environ. Agric. Food Chem. 8(3):201-208.

OJEH, O. 1981. Effects of refining on the physical and chemical properties of cashew kernel oil. J. Fats Oils Technol. 1b: 513-517.

OKULLO, J.B.L., F. OMUJAL, J.G. AGEA, P.C. VUZI, A. NAMUTEBI, B.A. OKELLO, and S.A. NYANZI. 2010. Physico-chemical characteristics of shea butter (Vitellaria paradoxa C.F. Gaertn.) oil from the shea districts of Uganda. Afr. J. Food Agric. Nutr. Dev. 10(1):2071-2084.

PEARSON, D.A. 1976. The chemical analysis of foods. $7^{\text {th }}$ ed. Edinburgh, UK: Scheckwahtong Printing Press. p. 488-496.

QUEVEDO, E.S, A.C. LAURENA, and F.E. MERCA. 2013. Physicochemical properties, nutritional and sensory quality of "batuan" [Garcinia binucao (Blco.) Choisy] fruits. Ann. of Trop. Res. 35(2):1-21.

RAO, C.V., H.L. NEWMARK, and B.S. REDDY. 1998. Chemopreventive effect of squalene on colon cancer. Carcinogen. 9(2): 287-290.

SALUNSKE, D.K., J.K. CHAVAN, R.N. ADSULE, and S.S. KADAM. 1992. World oil seeds: chemistry, technology, and utilization. p. 116, 170-173.

SHAHNAZ, H., A. HIFZ, K. BUSHRA, and J.I. KHAN. 2004. Lipid studies of Cuminum cyminum fixed oil. Pak.J. Bot.36(2):395-401.

SIDDHURAJU, P., K. BECKER, and H.P.S. MAKKAR. 2001. Chemical composition, protein fractionation, essential amino acid potential and antimetabolic constituents of an unconventional legume, Gila bean (Entada phaseoloides Merrill) seed kernel. J. Sci. Food Agric. 82: 192-202.

[SCUC] Southampton Centre for Underutilized Crop. 2006. Mangosteen, Garcinia mangostana, Field Manual for Extension Workers and Farmers. Southampton, UK: International Centre for Underutilized Crop. p21. 
TAJANLANGIT, E.F.J. 2011. “Garcinia binucao” In: The Good Life. Accessed on July 26, 2013 from: http://www.visayandailystar.com/2011/January/12/goodlife.htm

VIDHATE, G.S. and R.S. SINGHAL. 2013. Extraction of cocoa butter alternative from kokum (Garcinia indica) kernel by three phase partitioning. J. Food Eng'g. 17:117-182.

VISIOLI, F., L. BORSANI, and C. GALLI. 2002. Diet and prevention of coronary heart disease: the potential role of phytochemicals. Cardiovascular Res. 47: 419-425.

YAP, S.K.L. 2011. Characterization and lipid profile of malunggay (Moringa oleifera Lamk.) seed oil. Unpublished B.S. Thesis. University of the Philippines Los Baños, Laguna, Philippines. p28.

http: / / amrita.vlab.co.in/?sub=3\&brch=63\&sim=1111\&cnt=2; Horowitz, 1975 Accessed on: January 5, 2012

http://www.bhjc.com. Accessed on January 5, 2013.

http://www.getridofacne.co.uk/wp-content/uploads/2014/07/cocoa-butter.jpg. Accessed on August 17, 2014

http:www.uidaho.edu/ devs//Research/Calculators/ Molecularweights _ calculator.html. Accessed on:2/29/14 